\title{
TTR
}

Traduction, terminologie, rédaction

\section{Fulani Oral Literature and (Un)translatability: The Case of Northern Cameroon Mbooku Poems}

\section{Oumarou Mal Mazou}

Volume 28, numéro 1-2, 1er semestre-2e semestre 2015

Territoires, histoires, mémoires

Territories, histories, memories

URI : https://id.erudit.org/iderudit/1041652ar

DOI : https://doi.org/10.7202/1041652ar

Aller au sommaire du numéro

\section{Éditeur(s)}

Association canadienne de traductologie

ISSN

0835-8443 (imprimé)

1708-2188 (numérique)

Découvrir la revue

Citer cet article

Mal Mazou, O. (2015). Fulani Oral Literature and (Un)translatability: The Case of Northern Cameroon Mbooku Poems. TTR, 28(1-2), 109-131.

https://doi.org/10.7202/1041652ar

\section{Résumé de l'article}

Le présent article a pour objectif d'examiner la traduisibilité de la poésie orale peule du Nord Cameroun, notamment le mbooku, dans une perspective littéraire. Il s'appuie sur un corpus tiré de recueils de poèmes oraux transcrits et traduits en allemand, en anglais et en français par différents traducteurs. De l'analyse, il ressort que malgré les difficultés linguistiques et culturelles observées dans le processus de transfert chez les uns et les autres, il est possible de traduire les poèmes peuls en langues européennes pour que les textes d'arrivée assument la même fonction littéraire que les textes de départ. Ainsi, l'auteur propose une retraduction qui allie fond et forme, en respectant les canons de la poésie européenne moderne. Il appelle par conséquent à des retraductions de ces poèmes dans une perspective purement littéraire et souhaite que les études traductologiques s'intéressent davantage aux sources primaires de l'oralité. 


\title{
Fulani Oral Literature and (Un)translatability: The Case of Northern Cameroon Mbooku Poems
}

\author{
Oumarou Mal Mazou \\ Université de Liège
}

\begin{abstract}
This paper sets out to examine the translatability of Fulani oral poetry from Northern Cameroon, especially the mbooku genre, in a literary perspective. The corpus is gathered from selected oral poems that were transcribed and translated into German, English and French by different translators. The study reveals that it is possible to translate Fulani poems into European languages so that the target texts perform the same literary functions as the source texts, in spite of linguistic and cultural difficulties that occur during the transfer process. Thus, the author proposes a retranslation in which the content meets the form, taking into account some patterns of European modern poetry. He therefore advocates for retranslations of these poems from a purely literary perspective and would like to see translation studies focus more on the primary source of African orality.
\end{abstract}

Keywords: Fulani poems, retranslation, mbooku, oral literature, untranslatability

\section{Résumé}

Le présent article a pour objectif d'examiner la traduisibilité de la poésie orale peule du Nord Cameroun, notamment le mbooku, dans une perspective littéraire. Il s'appuie sur un corpus tiré de recueils de poèmes oraux transcrits et traduits en allemand, en anglais et en français par différents traducteurs. De l'analyse, il ressort que malgré les difficultés linguistiques et culturelles observées dans le processus de transfert chez les uns et les autres, il est possible de traduire les poèmes peuls en langues européennes pour que les textes d'arrivée assument la même fonction littéraire que les textes de départ. Ainsi, l'auteur propose une retraduction qui allie fond et forme, en respectant les canons de la poésie européenne moderne. Il appelle par conséquent à des retraductions de ces poèmes dans une perspective purement littéraire et souhaite que les études traductologiques s'intéressent davantage aux sources primaires de l'oralité.

Mots-clés: poésie peule, retraduction, mbooku, littérature orale, intraduisibilité 
To apparent untranslatability which results from structural incompatibilities between languages, one can respond with potential translatability with the possibility of expressing the concepts of human language. (Wilss, 1982, p. 35)

\section{Introduction}

With more than twenty million speakers in twenty African countries, Fulani is among the most spoken languages in Africa. In Cameroon, this Niger-Congo language group serves as lingua franca in almost all of the three administrative regions (Adamawa, Far North and North). Even though there are no official statistics, Lewis et al. (2014) estimate Fulani speakers in Cameroon at 669000 in $1986 .{ }^{1}$ The relatively rich Fulani oral literature in Cameroon accounts for the number of transcriptions of books and their translations into European languages, mainly English, German and French. Paradoxically, very few scholarly works have been devoted to this translated literature in the field of translation studies. This article attempts to address the issue of (un)translatability of Cameroon Fulani poems and is based on the analysis of two mbooku poems transcribed and translated into English, German and French. Results obtained revealed that this poetic genre is indeed translatable into European languages, despite the cultural distance and the difficulties that may occur at the level of form and content.

After a brief contextualization of the mbooku genre in the Cameroonian literary (poly)system, the article discusses the issue of poetry translatability in terms of various difficulties the translator may face in the process. Then follow the theoretical and methodological frameworks whereby the author justifies the choice of descriptive and functional approaches to translation studies in analyzing the material under study. Micro- and macro-analyses of the corpus reveal that the English, French and German translations of Cameroon mbooku poems do not reproduce its entire aesthetic and literary flavor. The analysis reveals that the skopos of the target texts differs from that of the source texts, resulting in what Nord (2005, p. 80) refers to as documentary translation. However, the translations may constitute a first step for further retranslations. Finally retranslations of some excerpts of the mbooku poems are

1. This number today may be doubled or even tripled with the population growth rate estimated at $2.5 \%$ in 2013. 
proposed to show that despite the cultural distance between the Fulani language and European languages, it is possible to translate Fulani mbooku poems in such a way that their skopos in the target languages can be the same as the one of the source texts.

\section{The Mbooku Genre in the Cameroonian Literary Polysystem}

Cameroon is considered as "Africa in miniature" because of its linguistic, cultural, religious and geographic diversity. The northern part of Cameroon with its three administrative regions (Adamawa, Far North and North Regions) counts more than 50 languages (Eguchi, 1993, p. 181), among which is the Fulani language. As in many other African countries, Cameroon's literature system was mainly oral until the advent of islamization, christianization and colonization that brought in written culture. The classification of Cameroon Fulani oral literature according to Eguchi (ibid.), is as follows: news, history (habaru/habaruuji); story, word (haala/ haalaaji); wit (kissawol/kissaaji, kiccawol/kiccaaji); short story, folk tale (taalol/taali); proverb (balndol/balndi); riddle (annditanamwoll annditanamji); magical formula (moccoore/moccooje), and poem, song (gimol/gimi) (ibid., p. 185).

Mbooku belongs to the last classification (poem/song). Researchers like Seydou (1993), Dalil (1988) and Eguchi (1978) define it as a genre of songs that are performed only by Fulani from the Far North Region of Cameroon (Diamaré division and beyond). More precisely,

le mbooku est une manifestation littéraire et artistique complexe, exigeant toute une troupe qui accompagne le récitant en repentant, suivant une mélodie et une chorégraphie sommaire mais bien réglée, un refrain rythmé, après chaque vers énoncé. (Seydou, 1993, p. 165)

Mbooku poems were popular amongst the Fulani people, and poets travelled a lot beyond their villages, regions and even to some neighbouring countries like northern Nigeria and Chad, where important Fulani communities live. People appreciate mbooku poems as entertainment, for their humorous peculiarity and the social satire they contain, but also for the linguistic prowess of the poets. As to the themes developed in those poems,

[o]n y retrouve des réflexions philosophiques sur le monde, des relations d'aventures personnelles, des récits historiques 
retraçant l'expédition allemande lancée contre le chef mousgoum Ziguila, des épopées comme celles de la famine, des critiques morales et sociales, et plus récemment des poèmes dithyrambiques à l'endroit de certains ou, à l'inverse, des insultes cristalisées autour d'un personnage symbolique. (Dalil, 1988, p. 15)

Today, the mbooku genre is among the endangered oral literatures because it is no longer performed in the region ${ }^{2}$. The situation can be explained mainly by the younger generations' lack of interest in traditional culture, and by the fact that almost all the entertainers have passed away or are too old to perform. Thus, mbooku poems survive only through audio tapes, CDs, scholarly publications on Fulani oral literature and of course, transcription and translation. Bibliographical research reveals that the first translated mbooku poem was published in 1978 by the Japanese Paul K. Eguchi, who collected poems in 1976 during a field research in North Cameroon (Eguchi, 1978, p. 55). Current data shows that mbooku poems have been translated into three European languages: English (Eguchi, 1978, 1980, 1984, 1992); German (Erlmann, 1979; Adama and Erlmann, 1986), and French (Dalil, 1988).

Scholarly works that involve Dalil's book either as subject matter or as quoted reference include Dieng (1989), Seydou (1993), and more recently Aissatou (2013), as well as MA and Ph.D dissertations in Cameroonian universities and abroad. Taking all this into account, there is no doubt that mbooku as a literary genre has been a subject of great interest in academic writings, be it in literature, linguistics, anthropology or other disciplines. Despite such a relatively rich corpora, with translations in at least three European languages, little has been written or said about African oral literature in general and Fulani mbooku poetry in particular in the field of translation studies. The few academic studies on the translations include those of Mal Mazou (2009, 2013a, 2013b). The present paper is therefore a contribution to introduce Fulani oral literature in the field of translation studies.

2. During a field research I made in 2014 in Maroua, Bogo, Balaza and other areas of the Far North region, I could not meet any mbooku singer, and we were told by locals that the genre is no longer performed live. 


\section{Poetry and the Myth of (Un)translatability}

In literary translation, poetry is said to be the most challenging amongst other literary genres like the novel, drama and the short story. The challenge lies in the fact that form and content are so closely related that they cannot be readily separated as in other genres. It is obviously the reason why the (un)translatability of poetry has been a topic for debate among translators and translation studies scholars. Robert Frost thinks poetry is what "gets lost in translation" (cited by Connolly, 2005, p. 170). Many other renowned scholars like Jakobson (1966, p. 238) hold poetry untranslatable by definition. House also thinks "[i]n poetry, the form of a linguistic unit cannot be changed without a corresponding change in (semantic, pragmatic and textual) meaning" (1997, p. 48).

Other translation scholars like Holmes believe that poetry can be translated if we use distinct strategies which he enumerates as "mimetic form" (when the original is retained), "analogical form" (when cultural correspondences are called upon), "organic form" (when the form of the original grows into the target text) and "deviant/extraneous form" (when the adapted form is new compared to the original) $(1988$, p. 25$)$. In the same vein, Lefevere proposes an approach consisting of seven methods that are adopted in translating Catullus poems into English: phonemic translation, literal translation, metrical translation, verse-to-prose translation, rhymed translation, free verse translation, and interpretation (Lefevere cited in Bassnett-McGuire, 1980, p. 81-82). Folkart also finds that "a poem in language $\mathrm{A}$ can always be reworded, one way or another in language B" even if successful translations, or "poetically viable translations are the exceptions" (2007, p.141). Although Folkart recognizes the difficulties in translating poetry (ibid., p. 488), her reflection on the issue makes us believe a successful translation of poetry is always possible.

Therefore, instead of untranslatability, it is more appropriate to talk of difficulty. Since translation is a purposeful activity (Nord, 1997) aiming at achieving a goal or a function in the target text, Fulani poems are translatable into European languages, though the level of difficulties here may be higher than they can be between two languages with similar cultural backgrounds. The difficulties translators have to face during the process of translation can be both at the level of form and at the level of content, as in any other literary translation. 


\section{Theoretical and Methodological Backgrounds}

The corpus examined in this study consists of excerpts from three different Fulani mbooku poems and their translations into English and French. The first poem is "Beeda", translated into English by Eguchi (1978), 241 lines. The poem is a lament about Beeda, a she-goat the poet received from Dumru village and which got lost when they arrived in Bogo after a long journey and all sorts of obstacles. The second poem is "Weelo" translated into French by Dalil (1988), 422 lines, a story about a famine that hit the whole northern region of Cameroon, killing many people, probably in the early $20^{\text {th }}$ century. The third is Erlmann's translation of the same poem "Weelo" (1979), but recorded from a different singer. The poem is shorter than the former and counts only 270 lines. The translators come from different backgrounds and even different continents. Eguchi is a Japanese anthropologist who spent more than twenty years in Maroua, working on Fulanis and their culture. Erlmann is a German ethno-musicologist who works on African folklore. Dalil is the only native speaker of Cameroon Fulani and is trained as a high school teacher and researcher in the field of linguistics. All three worked on the poems independently and at slightly different periods.

From the paratexts (introductions, forewords) accompanying the poems, it can be seen that the three translators have fixed the aims of their works. Eguchi seeks to introduce what he calls a "lyrical poem" to the international audience and to "examine the textual differences and similarities among four of Aakal's versions and to present for comparative purposes an additional text of Beeda as sung by Aadamu, a younger singer" (1978, p. 57). Dalil also aims to introduce texts collected from the repertoire of a single singer, and wishes to contribute by gathering a documentation for further studies in linguistics, musicology, philosophy, history or anthropology of the Fulani poems (1988, p.7). Erlmann, on his part, is more concerned with the ethno-musical aspect of the poems, even if the introduction of the genre to new audiences is amongst his main objectives $(1979$, p. 8$)$. The target readers of the various translations are also those who know Fulani languages, and that may be the raison-d'être of the juxtaposition of the source and target languages in the same documents.

The analysis of the corpus was based on the complementarity of descriptive and functional approaches to translation studies. 
From a descriptive point of view, the research aimed to observe how translations have been done in practice and "not to prescribe how translations ought to be done" (Kruger, 2000, p. 39). In other words, I describe the decisions and choices made by the translators in order to come up with the global strategy each translator has used to address the difficulties encountered during the language transfer. But instead of focusing on the target texts as advocated by Toury (2012, p. 18) I deem it more appropriate to borrow from Nord's functional approach, namely the translation-oriented text analysis, since it "provide[s] a reliable foundation for each and every decision which the translator has to make in a particular translation process" (Nord, 2005, p. 1). Nord's translation-oriented text analysis is based on the looping model, whereby the translation analyst needs to constantly go back and forth between the target and the source texts during the process. Therefore, while the descriptive approach allows us to analyze translators' decisions and strategies, the functional approach guides the re-translation of the poems with the assumption that the skopos (or the function) of the target text is the same as that of the source text, that is, aesthetic and literary.

The methodology used in the analysis consists in comparing the source and target texts using a tertium comparationis, that is, a third text obtained through line-for-line translation of the source texts. This third text will enable a better understanding of the translation process, as well as various decisions which led to transformations during the transfer process. The comparison is made at two levels: 1) at the microstructural level, where isolated extracts will be analyzed to describe potential difficulties and various choices made by the translators to address these difficulties in the target text; 2) at the macrostructural level; macrostructure analysis that "consists of a projection of results gleaned at the lower levels" (Hewson, 2011, p. 27) follows the microstructure analysis with the aim of verifying the effects of the translators' choices on the poem as a whole. Results of the analysis will help retranslate an excerpt of each poem, bearing in mind that the (virtual) function assigned to the re-translation is mainly literary and aesthetic. In other words, the target text receptors are to perceive the translated poems not as translations but as poems written in their target language, keeping in mind some patterns of modern poetry like stanzas, rhythm, and rhyme, to name a few. 


\section{Microstructural Level Analysis}

Microstructure analysis consists in identifying source text passages and their corresponding target text passages. This allows one "to concentrate on specific points, and examine the ways in which they [the texts] have been translated" (Hewson, 2011, p. 27). Three types of difficulties will be of interest in this section: lexical, stylistic, and cultural.

\subsection{Lexical Difficulties}

The choice of lexis by the poet to construct his poems is very important and is not made haphazardly. Lexical items determine the rhythm, rhymes and structure of the text. Below are examples of some difficulties and the choices made by the translators in their respective translations:

Daga Dumru mi dow Beeda.

Nden boo Beeda meemaaka.

Ngar-mi Kuusu. Be kuusaay nga.

Biiseele be ceelaay nga.

(Eguchi, 1978, p. 68, lines 11-14)
[Since Dumru I pulled Beeda on a leash]

[Even then Beeda was not touched]

[I came at Kuusu. They didn't cut her]

[In Biiseele they didn't strip her]

From Dumru I accompanied Beeda.

Even then she was not touched,

I came to Kunsu. They did not slaughter her.

In Biiseele, they did not cut her meat into strips.

(Eguchi, 1978, p. 69, lines 11-14)

(2)

yee6i naati nder Papata

[tiptoed, entered Papata]

liintaniingo Amma Baru

[she searched from Amma Baru]

Amma Baru ko daanin ma

[Amma Baru why do you sleep]

mi daanaaki mi wad dum non

[I don't sleep, I just pretend]

(Erlmann, 1979, p. 192, lines 66-69)

(Sie) schlich und kam nach Papata [(She) turned and went to Papata] hinein

Und öfnete (die Tür) von Amma Baru

[And opened (the door) of Amma Baru] 
(und sagte:)"Mutter Baru, was brachte dich zum Schlafen?"

(Mutter Baru sagte:) "Ich schlafe nicht, ich tue nur so."

(Erlmann, 1979, p. 193, lines 66-69) [(and said:) "Mother Baru what brought you to sleep?"]

[Mother Baru said: "I'm not sleeping I'm only pretending."]
Weelo $^{(\mathrm{dw})}$ faltani Daada Baru

Weelo meyi mo bee cimatel

"Daada Baru ko dannin maa?

A haaray ko dannin maa?"

Daada Baru ko jaabii ngo "naa mi daani mi waddum non" (O. Dalil, 1988, p. 142, lines 82-87)
[Hunger forced Daada Baru's door] [Hunger touched her with her auricular]

[Daada Baru why do you sleep?]

[You are not satiated, why do you sleep]

[Daada Baru what she answered her?] [It is not that I sleep, I just pretend]

La famine déverouilla [la porte de] la mère Barou

La famine la toucha de l'auriculaire:

"Hé! Mère Barou, qu'est-ce qui t'endort?

Tu n'as pas le ventre plein, pourquoi dors-tu?»

Ce que lui répondit la mère Barou?

"Ce n'est pas que je dors, c'est plus fort que moi".

(Dalil, 1988, p. 143, lines 82-87)

In (1), the Fulani word "dow" means to pull an animal using a rope (goats, donkeys, horses, and the like). Generally, in this case, the animal is behind the person who pulls it. The image is that of the character of the source text walking and the goat being pulled behind him. Also, the quest for sounds is attested in the last two lines (Kuusu/kuusaay; Biiseele/ceelaay). Kuusu and Biiseele are the names of the villages through which Beeda passed without being stolen. The phrase "be kuusaay" means "they did not cut", while "be ceelaay" means "they did not cut out." The translation of "dow Beeda" as "accompanied Beeda" changes the perspective created by the source text. In the target text, Beeda seems to be in front, while the poet follows. Eguchi uses the technique of modulation (to convey the idea of pulling). On the other hand, wordplays contained in the source text have been lost in the target text. In fact, the translation 
shows also a modulation- "slaughter"-for the first wordplay, and an explicitation in the second: "cut her meat into strips." These modulation and explicitation techniques make the target text lines longer than the one in the source text, modifying the feet number and thus altering the rhythm.

In (2), "lintaniingo" can be rendered by "s/he searched”, "ngo" being an implicit reference to "weelo" [hunger]. In this context, it can also mean she entered Dada Baru's hut like a burglar. Hunger is thus personified and is given a human behavior. This personification is asserted by the dialogue between hunger and the old woman, in direct speech. The German translation presents a lot of additions the translator materialized with parentheses (Sie), (Die Tür), (und sagte), or (Mutter Baru sagte). In addition, Erlmann uses free indirect discourse technique (Hewson, 2011, p. 82), where the source text shows direct discourse as in the dialogue between hunger and Dada Baru. It allows him to overcome the difficulty of the impersonal tone the poet uses, by eliminating personal pronouns, or markers of dialogue. However, it makes the target text lines longer than the source text as discussed in (1). Besides this, implicit information contained in "lintaniingo" is made explicit in the target text phrase "Die Tür", which is materially absent in the source text. Again, addition and explicitation are the techniques used by the translator to deal with some difficulties that occur in the transfer of Fulani ideas in German.

Example (3) also shows techniques of addition, explicitation and modulation. In fact, by translating "faltani" [unblocked] as "déverrouilla la porte de", Dalil, like Erlmann, has produced additional information (la porte) implicitly mentioned in the source text. He also added the onomatopoeia "Hé!" as well as an endnote materialized by the indication (dw) on the word "weelo", which is further explained at the end of the book. Modulation is found in the last line of the extract, whereby "mi waddum non" [I just pretend] is rendered as "c'est plus fort que moi," even leading to a mistranslation. The English, German and French translations tackle the difficulties of Fulani lexical items with techniques such as addition, explicitation, modulation and endnotes, with various degrees of success. Of course, most of the content is rendered through these techniques, but to the detriment of fundamental patterns in the poems (rhythm, meter, sound and structure). 


\subsection{Stylistic Difficulties}

Stylistic construction in the source text is important to consider when translating a poem, since it is one of the important patterns that makes a poem different from other writings (literary and pragmatic texts). The following are examples in which a stylistic formulation of the source text may impose a specific choice on the translator.

Beeda am nga, to nga halkaay-no, [This my Beeda, if she was not lost,] nga waata lagammbe teemerre. [She would put one hundred bridles.]

Beeda am to nga halkaay-no, [This my Beeda, if she was not lost,] gursaaje nga waddantam.

Nga waddana-mmi girkaadi. [Silver coins she would bring me.] (Eguchi, 1978, p. 78 and 80, lines 180-186)

If my Beeda had not disappeared, she could have brought me a hundred bridles. If my Beeda had not disappeared, she could have brought me Maria Theresa dollars. She would have brought me gowns. (Eguchi, 1978, p. 79 and 81, lines 180-186)

$\begin{array}{ll}\text { Calludi calitii mboo'en } & \text { [Calludi rebuffed 'mboo'en'] } \\ \text { yoofi cidi 'e zawleeji } & \text { [left moisture in the lobbies] } \\ \text { talaka kacuko ndaaynee min } & \text { [Smelly poors go far from us] } \\ \text { duuda buubi dawol fajiri } & \text { [full of flies, early morning visitors] } \\ \text { bikka kam nde nginam fowru } & \text { [this year is like hyena swim] } \\ \begin{array}{l}\text { ngulu bakkude yaali 'en } \\ \text { moye fuu tayra bone muudum }\end{array} & \text { [beard-burning passed through us] } \\ \text { (everyone fights on his own] }\end{array}$
(Erlmann, 1979, p. 192 and 194, lines 99-105)

Calludi hat die mboo'en abgewiesen und

[Calludi has dismissed the mboo'en and]

Ließ die Wasserflecken in den Eingangshütten

[left water stains in the vestibules] 
(Sie sagten zu den mboo'en:) "Laßt uns in

Ruhe (ihr) Armen

mit vielen Fliegen am frühen Morgen

Dieses Jahr schwimmen die Hyänen.

Der Brand der Bärte geht (nur) uns an

Jedermann verbringe die Regenzeit

durch eigene Mühe."

(Erlmann, 1979, p. 193 and 195, lines 99-105)
[(They said to the mboo'en:)] "leave us

[alone]

[with many flies in early morning]

[this year is hyena swimming.] Beard burning passes through us]

[anyone should cross the rainy season] through his own efforts."]

(6)

Laambe baa ${ }^{(e o)}$ calitii wiirbe

"Koya kaccuko ndaaynee min

Kacciranko ba nyuunyuuje

Duuda buubi dawol fajiri

Hikka ndee nginam fowru

Mone fuu da'ara bone muudum

(O. Dalil, 1988, p. 154, lines 234-239)

Même les lamibé rabrouèrent les courtisans:

"Éloignez-vous de nous, espèces de puanteurs!

Vous qui puez comme colonnes de grosses fourmis noires

Et [qu'envahissent] de nuées de mouches le matin dès l'aube.

Cette année, c'est chacun pour soi $i^{(173)}$

Chacun doit se débrouiller tout seul

(Dalil, 1988, p. 155, lines 234-239)

"Lagammbe teemerre" [one hundred bridles] in (4) above is a trope. It is a "metomymic metaphor," to use Grimaud's terminology (1978). Literal translation into English will be "one hundred bridles." But in this context, it is figurative speech to refer to a significant number of horses. Horses in Fulani society symbolize power and wealth, since only powerful and rich people can afford them. According to the author of the source text, Beeda would have given him power and wealth in such a way that he can buy a hundred horses and consequently be as powerful as a king, if only 
she had not been lost. The translator retains the literal meaning in the English translation, without taking time to find an equivalent metaphor in English whereby a horse is equally a symbol of nobility and royalty. In this literal translation, the metonymy does not work in the same way, i.e. we do not necessarily see horses, or think of power when we hear "bridle."

Popular expressions like "hikka kam nde nginam fowru" [this year is hyena swimming] and "ngulu bakkude yaali "en" [beard burning has happened to us] (5) are generally used by the Fulani to refer to a difficult situation that calls for an individualistic behaviour. In the poem, a village named Calludi where the mboo'en used to go and perform refuses to welcome them claiming that they are poor and smelling. The German target text renders these idiomatic expressions literally as "Dieses Jahr schwimmen die Hyänen" [this year is hyena swimming] and "Der Brand der Bärte geht (nur) uns an" [Beard burning passes through us] respectively. Consequently, as in (4), the actual echo in the source language is lost in the German translation.

The exact expression "hikka kam nde nginam fowru" is found in Dalil's text (6) in the same context, the only difference being the setting. Here instead, the poet alludes to traditional rulers who, in normal conditions, take care of their courtiers, meet all their living needs such as food, clothes and health. In the event of a natural disaster like hunger, they cannot do so. The courtiers are therefore advised to fight for their survival until the end of the disaster. The French translator has rendered this idiomatic expression using another French idiomatic expression "c'est chacun pour soi." Besides this, he has added further information by giving a literal translation as endnote (materialized by the endnote reference 173). This additional information appears to be redundant since the reader of the target text understands clearly the selfishness contained in the French "c'est chacun pour soi."

\subsection{Cultural Difficulties}

Other forms of difficulties encountered in Fulani mbooku poems are cultural references. Several studies on translating cultural references have been carried out, among which Leppihalme $(1994,1997,2000)$ and Hatim (1997). They are a great challenge for translators when languages/cultures involved are very different as is the case with Fulani and European languages. Mbooku poems are deeply rooted 
in Fulani culture, and it is no surprise to find a very considerable (or significant) amount of cultural references in the poems. The following examples are cultural references and their translations in the respective target languages:

(7)

Bogo $0^{\circ}$ Gariire $e^{p}$ nga ruumaayi.

Nga wari Duumu $u^{q}$ ga ruumaayi.

Moobti muuri be ndawrani nga.

Muuri benndi be njari Beeda.
[In Bogo Garrire she didn't pass the rain.]

[She came to Duumu, she didn't pass the rain.]

[Gathered millet they plot on her.]

[The millet ripened they drank

Beeda.]

(Eguchi, 1978, p. 70 and 72, lines 51-54)

In the big town of Bogo she did not stay till the end of the rainy season. She came to Duumu, and did not stay to the end of the rainy season. After gathering millet, they plotted to steal her. The millet ripened, and they drank Beeda's milk. (Eguchi, 1978, p. 71 and 73, lines 51-54)

Weelo wadata kam bondum

Naati Dargala jeeriire

Dargala ha6i bee Booray

Maayo ni woni keerol men

Taydo maayo fuu maayan

(Erlmann, 1979, p. 202, lines 241-245)
[What hunger does is wicked] [Entered Dargala the cold city] [Dargala fought with Booray] [The river is then our border] [He who ever crosses the river will die]
(Was) die Hungersnot tut, ist schlecht.

(Sie) kam nach Dargala binein.

Dargala kämpfte mit Booray.

(Sie sagten:) der Fluß ist unsere Grenze.

Jeder, der den Fluß überquert, wird sterben".

(Erlmann, 1979, p. 203, lines 241-245)
[What the famine does is wicked.]

[(She) came to Dargala.] [Dargala fought with Booray.]

[(They said:) the river is our borderline.]

[He who crosses the river will die.] 
Weelo naati Dargalla

Dolwo ha6i e laamorde

Ngam sabiida piitoore

"Joldo maayo fuu maayan

Maayo ni woni keerol men"

(Dalil, 1988, p. 158, lines 302-306)
[Hunger entered Dargalla]

[Dolwo fought with Laamorde]

[Because of the piitoore]

[He who ever crosses the river will die]

[The river is then our border]

La famine fit son entrée à Dargala

Le quartier Dolwo guerroya contre celui du lamido

Et cela pour des fruits de "pitôhi"(183)!

"Quiconque traverse la rivière est un homme mort"!

(Dalil, 1988, p. 159, lines 302-306)

Gariire and Duumo (7) are praise names of the Bogo village, the residence of the poet. Gariire qualifies the Bogo and is a borrowed word from Hausa. In fact, in the Hausa language, "gari" means "city". Therefore, "Bogo gariire" can be translated as "Bogo the beautiful city." Similarly, Duumo is the river that flows in Bogo. In northern Cameroon, villages are praised using the names of the natural elements that characterize them such as rivers, mountains, hills, deserts and many more. Thus, the praise name of Bogo is known to be "Bogo Duumu." Praise names are cultural, and every community has its own way of using them. Eguchi used literal translation in the English translation as "the big city of Bogo." Moreover, he opted for footnotes in which he put the source text transcription with references ( ${ }^{\mathrm{o}, \mathrm{p}}$ and ${ }^{\mathrm{q}}$ respectively) to provide background information for each name. These footnotes are shown as follows:

o. Bogo is the town where Aakal has been living for most of his life. Aakal used to sing for Chief Hammadu. He eulogizes him in Giiwa maa naywa 'May the great chief live long'. Bogo has been ruled by the following chiefs: Ujiri, Umara, Sammbo, Gaare, Usmaanu, Hammadu, Buuba.

p. Gariire borrowed from Hawsa (garii) is a kind of epithet given to big towns such as Bogo, Maroua, Garoua, etc.

q. According to an informant, Duumu came from duum'last, endure', and signifies 'eternity, longevity, endurance' of 
the town as well as the river running in the north of Bogo which always has water in it, and never dries up (Eguchi, 1978, p. 70, n. o and q).

One may agree with Blight that " $[\mathrm{w}]$ hen a translator inserts background information into the text, the translation may seem to include the translator's own statements, not those of the original author" (2005, p. 9). These translator's own statements, variously referred to as translator's visible traces (Batchelor, 2009), translator's deliberate interventions (Bastin, 2007) or translators' visibility (Venuti, 1995), are controversial among translation scholars. Some like Bensoussan (2005) consider translator's notes as a sign of weakness while for others they can be normal solutions, almost conventional (see Henry, 2000, p. 238). Of course, it may become annoying to read a poem with footnotes covering a quarter of the page.

In (8), another praise-name is used for the Dargala village, referred to as "Dargala jeeriire" whose literal translation is "Dargala the beautiful city." The excerpt describes how Dargala dwellers fought with those of Booray, a neighboring village with which a river constitutes a natural frontier. Erlmann's translation of "naati Dargala jeerire" as "(Sie) kam nach Dargala hinein" reveals an omission of the praise name "jeerire." One of the solutions would have been to leave it as such in the target text.

Other types of cultural names are available in "Weelo" translated into French by Dalil (9). In fact, in the same context as in (8) names for a village "Dargalla," for neighbourhoods "Dolwo" and "laamorde," and for a wild fruit "piitoore" are used by the poet in the source text. A stress is put intentionally on the name Dargala by doubling the "l". While "Dar" is a loanword from the ArabChoa language (the village), "galla" is another way to name food in Fulaani. Coining a word through the combination of the two words form "Dargalla" is a technique to implicitly mock the greediness of Dargala dwellers. On the other hand, Dolwo and Lamorde, which are known as neighbourhoods in Bogo, are not qualified in the source text. The name "piroore" is also left unqualified. However, the French target text omits the stress on the "l" in Dargala, adds information "Le quartier de" to Dowlo and uses an endnote $\left({ }^{183}\right)$ to give the following background information at the end of the book: (Piitoohi: arbre, ie Afzelia aficana Smith. Césalpinacées). In 
addition, Dalil also adds when he translates "piitoore" as "le fruit de "piitôhi'," thus transferring the source name in the target text with a modified spelling and additional information. These translation choices make it more difficult for readers who are not familiar with Fulani cultural references to understand the target text.

From the above microstructural analysis, we can understand that the three translators used similar translation techniques such as literal translation, addition, explicitation, modulation, omission, footnotes and endnotes to tackle lexical, stylistic and cultural problems posed by the translation of Fulani mbooku poems into English, German and French.

\section{Macrostructural Analysis}

Lower level (microstructural) analysis has revealed translation choices such as literal translation, addition, explicitation, modulation, free indirect discourse, endnotes and footnotes, which are common to all three translators. If we consider only footnotes and endnotes because they are readily quantifiable at the macrostructural level, the results are as follows:

(1) Endnotes: Dalil's "Weelo" reveals an important number of endnotes at the end of the book, with Latin alphabets as reference numbering for the source text and Arabic numerals for the target text. In total, 19 Arabic numerals are used to add more meaningful information to some words and phrases, while 55 endnotes serving as a bilingual glossary for words/phrases that do not have immediate corresponding translations into French are under Latin alphabet references. Most of the time, such words/phrases are left unchanged or slightly modified in the target text. Erlmann also used endnotes immediately after "Weelo" and its German translation, under what he calls "Anmerkungen" for both the source and target texts. These endnotes are also additional explanations of difficult words/phrases and other grammatical and lexical formations of Fulani words. Hence, 29 words are explained for the source text and 24 for the target text with the poem line-number as reference. (Note: Erlmann has numbered all lines in the poem, while Eguchi and Dalil have chosen to number them by ten).

(2) Footnotes: Eguchi chose footnotes to bring further paratextual information to the source and texts. In total, 76 footnotes are materialized, using a combination of Latin alphabets and Arabic 
numerals, into the entire poem. Table 1 below is a summary of endnote and footnote techniques used by the three translators in their respective source text and target text ${ }^{3}$ :

Table 1. Number of endnotes and footnotes used by the translators

\begin{tabular}{|l|l|l|l|}
\hline & Eguchi & Erlmann & Dalil \\
\hline Endnotes & - & 53 & 74 \\
\hline Footnotes & 76 & - & - \\
\hline Percentage & $\mathbf{3 1 . 5 2 \%}$ & $\mathbf{2 8 . 1 4 \%}$ & $\mathbf{1 7 . 4 9 \%}$ \\
\hline
\end{tabular}

Those translators' deliberate interventions (Bastin, 2007, p. 39) like addition, explicitation and free indirect discourse, and endnotes and footnotes, reveal that the aim of the three translators is primarily to inform foreign readers about the existence of the mbooku genre. It is therefore obvious that the English, French and German translations of Cameroon mbooku poems do not reproduce their entire aesthetic and literary flavor. However, they constitute a first step for further retranslations.

\section{Retranslation of “Mbooku” Excerpts}

Retranslating means translating a second time or more. One can retranslate from the "first" source text into the same target language, that is, the language in which it was first translated, from the original "source" text into (a) new target language(s), or from the first target language (or the "second" source text) into new language(s). The importance of retranslation no longer needs to be demonstrated. "Il faut retraduire parce que les traductions vieillissent, et parce qu'aucune n'est la traduction," Berman said (1990, p. 1). The retranslation of excerpts has as its starting point the first target languages in which mbooku poems were previously translated: English into English for Eguchi's excerpt, and French into French for Dalil's translation. My understanding of Cameroon Fulani language and culture is also of great help. For copyright reasons, retranslations are limited to only 20 lines of Eguchi's and Dalil's translations.

3. The percentage presented in Table 1 is based on the lines' total numbers in the whole poems. 
(10)

\section{"Let us cry for Beeda"}

Now, sing in chorus.

Beeda, Nadda's daughter,

Layaajiiwa's granddaughter.

There were no places where Beeda did not go.

There were no bushes into which she did not go.

She passed through rivers full of water,

in the Moslem land and the pagan. Even then she did not disappear.

Now, sing in chorus.

She came from Dumru.

From Dumru I accompanied Beeda

Even then she was not touched,

I came to Kuusu. They did not slaughter her.

In Biiseele, they did not cut her meat into strips.

I crossed the Sapanaare river,

Where the Moundang pagans were wandering.

She was not carried off by them either, and they let Beeda pass.

There is no bush like that of Laara.

The Laara people saw her, but did not touch her.

(Eguchi, 1978, Line 1-19, p. 55)

\section{«La famine"}

La famine fit son entrée dans Papata,

Renversant les jarres de bière à coups de pied.
"Let us mourn Beeda"

Now chant the chorus

Beeda was Nadda's daughter

And Layaajiiwa's granddaughter

No place Beeda has not been

No bush Beeda has not entered

Rivers full of water, she cross'd

From Muslims' to Pagans' land

Even then, she had not been lost

Now chant the chorus

Her origin was from Dumru

From Dumru I pulled Beeda

Even then, she hadn't been touch'd

I reached Kuusu, they didn't cut her

At Biseele, they did not strip her

Sanganaare River I have crossed

Where Mbana pagans use to wander

She was not attacked she was not ripped

No bush bigger than Laara's

Laara watched her but did not touch her

\section{«Dame Famine"}

Famine à Papata s'invita

Des pieds, les jarres de bière elle renversa 
La famine déverouilla [la porte de] La porte de Dada Barou elle força la mère Barou

La famine la toucha de l'auriculaire: Puis de son petit doigt elle la toucha:

"Hé! Mère Barou, qu’est-ce qui t'endort?

Dada Barou, pourquoi t'endors-tu

Tu n'as pas le ventre plein, pourquoi T'es pas repue, pourquoi dors-tu? dors-tu?"

Ce que lui répondit la mère Barou? La réponse de Dada Barou?

"Ce n'est pas que je dors, c'est plus «Je ne dors pas, je fais semblant» fort que moi."

Ngaba Semait, Malam Déterrait [les semences]

Ils s'affrontèrent à coups de bâtons ${ }^{(37)}$

A cause des jeunes pousses.

Ngaba semait, Malam déterrait

À coups de bâtons, ils se battirent

La bataille de Badr ${ }^{(155)}$ a eu bien lieu

Mais ne fut rien comparée à cellelà.

De Petté, elle expulsa un jour d'algayta

Il passa l'hivernage à jouer dans les villages païens

$\mathrm{Il}$ jouait pour gagner du mauvais mil

"Qu'il est bon, le mille de Banna(156)

Qu'on donne à moudre aux molaires."

Elle s'emporta, défonçant le gros tambour

Elle qui imposa une canne à tout Fadare

Mourgoune ne suçait point de grain.

Pour simplement des jeunes pousses

Certes la guerre de Badr bien eut lieu

Mais face à celle de Ngaba ne fut rien

De Pette le joueur de flûte elle chassa

Chez les païens tout l'hivernage, il joua

Il jouait pour du mauvais mil

«Que le mil de Banna est bon!

Qui se fait moudre sous les molaires.»

Fâchée, elle faucha le gros tambour

Imposa la canne à Fadare

Point de grain à sucer pour

Mourgoune

(O. Dalil, 1988, 1. 80-100, p.143)

In the above retranslations, priority is given both to the form and content. At the formal level, I attempted as much as possible to reduce the length of the lines, thus coming up with a better 
rhythm. For exemple, instead of "there were places where Beeda did not go", I proposed a shorter line "No place Beeda has not been", removing therefore all the additions the first translator opted for. I also divided the poems into stanzas for better breathing. At the level of content, I reproduced some of the stylistic devices such as personification (the title "Dame Famine" instead of "La famine") and introduced some inversions ("Des pieds, les jarres de bière elle renversa") for the sake of rhythm. I also took out all the endnotes/ footnotes initially found in the first translations.

\section{Conclusion}

This study has pointed out lexical, stylistic and cultural difficulties Cameroon mbooku poems pose to translators and the various translation techniques the translators of such poems have used to tackle these difficulties. Micro- and macrostructural analyses reveal techniques such as literal translation, addition, modulation, omission, footnotes, endnotes and free indirect discourse as most frequently used in the translation process. The results of the analysis show that translators are mainly concerned with the content of the poems, thus sacrificing the aesthetic and literary functions of the source text. However, when taking these functions into account, translating Fulani poems into European languages is not impossible, though the task seems to be very difficult. Retranslation attempts of some excerpts from the same poems into English and French confirm the possibility of having a target text that contains most of the pertinent patterns found in the source text, when keeping in mind that the purpose of the target text shares the same function as the source text, i.e. a poetic, aesthetic or literary function. Retranslation of Fulani mbooku poems and all other forms of African oral literature will contribute not only to its preservation but also to the introduction of Fulani oral literature into the field of translation studies.

\section{References}

Adama, Souleymane and Veit Erlmann (1986). "Konu Raabe. A Fulbe Booku Song on Rabih b. Fadlallah." Africana Marburgensia, XIX, 2, pp. 79-95.

Aissatou (2013). "Poésie traditionnelle peule: le mbooku et la formation de la jeunesse." In C. Dili Palaï and M. Etuge Apuge, eds. Langage, littérature et éducation au Cameroun/Language, Literature and Education in Cameroon. Paris, L'Harmattan, pp. 99-120. 
Bassnett-McGuire, Susan (1980). Translation Studies. London, Methuen. Bastin, Georges L. (2007). "Histoire, traductions et traductologie." In G. Wotjak, ed. Quo vadis Translatologie? Ein halbes Jabrhundert universitäre Ausbildung von Dolmetschern und Übersetzern in Leipzig. Berlin, Frank and Timme, p. 35-44.

Bensoussan, Albert (2005). Confessions d'un traître. Essai sur la traduction. Rennes, Presses universitaires de Rennes.

Berman, Antoine (1990). "La retraduction comme espace de la traduction." Palimpsestes, 4, pp. 1-7.

Blight, Richard C. (2005). "Footnotes for Meaningful Translations of the New Testament." Journal of Translation, 1, 1, pp. 7-46.

Dalil, Oumarou A. (1988). Mbooku. Poésie peule du Diarnaré (NordCameroun). Paris, L'Harmattan.

Dieng, Samba (1989). La geste d'El Hadj Omar et l'islamisation de l'épopée peule traditionnelle. Thèse de doctorat d'État, Université Cheik Anta Diop de Dakar. Unpublished.

Eguchi, Paul K. (1978). "Beeda: A Fulbe Mbooku Poem." Senri Ethnological Studies, 1, pp. 55-88.

Eguchi, Paul K. (1980). “The Wood Ibises. A Fulbe Mbooku Poem.” Senri Ethnological Studies, 6, pp. 125-152.

Eguchi, Paul K. (1984). "Let us Insult Pella: a Fulbe Mbooku Poem." Senri Ethnological Studies, 15, pp 197-246.

Eguchi, Paul K. (1992). "The Europeans are not Good: A Fulbe Mbooku Poem of Protest." Senri Ethnological Studies, 31, pp. 465-480.

Eguchi, Paul K. (1993). "Fulbe-ness' in Fulbe Oral Literature of Cameroon.” Senri Ethnological Studies, 35, pp. 181-200.

Erlmann, Veit (1979). Booku, Eine literarisch-musikalische Gattung der Fulhe des Diamaré (NordKamerun) [Booku, A Literary Musical Genre of Fulanis from Diamaré (Northern Cameroon]. Berlin, Verlag von Dietrich Reimer.

Folkart, Barbara (2007). Second Finding: A Poetics of Translation. Ottawa, University of Ottawa Press.

Hatim, Basil (1997). Communication across Cultures: Translation Theory and Contrastive Text Linguistics. Exeter, University of Exeter Press.

Henry, Jacqueline (2000). "De l'érudition à l'échec: la note du traducteur." Meta, 45, 2, pp. 228-240.

Hewson,Lance (2011).An Approach to Translation Criticism.Amsterdam/ Philadelphia, John Benjamins.

House, Juliane (1997). Translation Quality Assessment. A Model Revisited. Tübingen, Gunter Narr.

Leppihalme, Ritva (1994). Culture Bumps: On the Translation of Allusions. 
Helsinki, Helsinki University Press.

Leppihalme, Ritva (1997). Culture Bumps: An Empirical Approach to the Translation of Allusions. Clevedon, Multilingual Matters.

Leppihalme, Ritva (2000). "Caution: Culture Bumps. On Cultural Literacy as a Goal in Translator Training." In B. Englund Dimitrova, ed. Översättning och tolkning. Rapport från ASLA:s höstsymposium, Stockholm, 5-6 Nov. 1998 [Translation and Interpreting: Report of the ASLA Autumn Symposium 1998]. Uppsala, ASLA, pp. 219228.

Lewis, Paul M. et al., eds. (2014). Ethnologue: Languages of the World. Dallas, SIL International. [http://www.ethnologue.com].

Mal Mazou, R. Oumarou (2009). La traduction de l'bumour dans Mbooku. Mémoire de Master, Université de Buea. Unpublished.

Mal Mazou, R. Oumarou (2013a). "Analyse des stratégies utilisées dans la traduction des injures du peul en français et en anglais." Paper presented at the Colloque International "Impliciter, expliciter: le traducteur comme équilibriste interculturel." Liège, Université de Liège, 2-4 May.

Mal Mazou, R. Oumarou (2013b). “(Re)Translating Cameroon Fulani Poems into English: Challenges and Perspectives." Paper presented at the International Conference on Literary Translation "Version, Subversion: Translation, the Canon and its Discontents." Porto, University of Porto, 12-14 December.

Nord, Christiane (1997). Translating as a PurposefulActivity: Functionalist Approaches Explained. Manchester, St. Jerome.

Nord, Christiane (2005). Text Analysis in Translation: Theory, Methodology, and Didactic Application of a Model for Translation-Oriented Text Analysis. Second ed., Amsterdam and New York, Rodopi.

Seydou, Christiane (1993). "Unité et diversité du monde peul à travers sa production littéraire: quelques aperçus." Senri Ethnological Studies, 35, pp. 163-179.

Toury, Gideon (1995 [2012]). Descriptive Translation Studies - and Beyond. Amsterdam/Philadelphia, John Benjamins.

Wilss, Wolfram (1982). The Science of Translation: Problems and Methods. Tübingen, Gunter Narr.

Oumarou Mal Mazou

Rue Alfred Defuisseaux, 37

4040 Hestal

BELGIQUE

rmazou@doct.ulg.ac.be 